\title{
Effect of disturbance on litter dynamics in moist tropical forest of eastern Nepal
}

\author{
Tilak Prasad Gautam ${ }^{* *}$ and Tej Narayan Mandal ${ }^{2}$ \\ ${ }^{1}$ Department of Botany, Mahendra Morang Adarsha Multiple Campus, Tribhuvan University, Biratnagar, Nepal \\ ${ }^{2}$ Department of Botany, Post Graduate Campus, Tribhuvan University, Biratnagar, Nepal \\ "E-mail: tilakg673@gmail.com
}

\begin{abstract}
Litterfall is an important vector of nutrient and carbon recycling in forest ecosystems. Present study was conducted in moist tropical forest of eastern Nepal to understand the effect of disturbance on litter dynamics. Litterfall was estimated at monthly intervals from one litter trap $(1 \mathrm{~m} \times 1 \mathrm{~m})$ at each of the 70 sampling plots while litter mass accumulated at each sampling plot was collected once every season from one $1 \mathrm{~m} \times 1 \mathrm{~m}$ plot. The total annual litterfall in undisturbed forest (UF) was $11.8 \mathrm{Mg} \mathrm{ha}^{-1} \mathrm{yr}^{-1}$ which decreased by $54.2 \%$ in disturbed forest (DF). Leaves accounted for $69 \%$ (UF) to $76 \%$ (DF) of total litterfall while non-leaf litter formed the rest. Seasonal pattern exhibited a concentrated litterfall in summer season during March to June when more than $70 \%$ litterfall occurred in both stands. Forest floor litter mass also decreased due to forest disturbance. The total input of nutrients to the soil through litterfall in UF was more than double as compared to DF. The nutrient stocks in litter mass were in the order: $\mathrm{N}>\mathrm{K}>$ $\mathrm{P}$ in both stands. Key disturbance activities like lopping, litter removal, tree felling, grazing, fire etc. in the peripheral part of the forest should be strictly prohibited by imposing rules and regulations so that status of biodiversity would be restored.
\end{abstract}

Key words: Litter fall, Litter mass, Nutrient stocks, Sunsari District

DOI: http://dx.doi.org/10.3126/on.v14i1.16435

Manuscript details: Received: 20.07.2016 / Accepted: 11.10.2016

Citation: Gautam, T.P. and T.N. Mandal 2016. Effect of disturbance on litter dynamics in moist tropical forest of eastern Nepal. Our Nature 14(1):1-12. DOI: http://dx.doi.org/10.3126/on.v14i1.16435

Copyright: () Gautam and Mandal 2016. Creative Commons Attribution-NonCommercial 4.0 International License.

\section{Introduction}

Senesced leaves, dead twigs, bark, flowers and fruits fall to the ground comprise ab- oveground litter whereas fine roots constitute the belowground litter. Both types of litter serve as the forest nutrient pool link- 
ing inputs, output and turnover of nutrients. Litter determines the amount of light reaching the soil, controls temperature, moisture, and also prevents the growth of young shoots, release chemical compounds on the soil and controls microbial activities.

Litter is a key factor in structuring plant populations, through positive or negative interactions (Baltzinger et al., 2012). Thick layer of litter found in temperate forests alters the growth of seedlings and adult plants, thereby reducing the species diversity and biomass of ground vegetation. On the other hand, the thin layer of litter due to readily decomposition in moist tropical forests favours the growth of seeds and seedlings and increase the species diversity and biomass.

Litterfall not only constitutes a large fraction of net primary production (NPP) but also serves as a medium for nutrient cycling between the vegetation and soil. It contributes over $80 \%$ of the nitrogen and phosphorus, and $77-100 \%$ of the calcium returns to the soil (Hansen et al., 2009). Litterfall is suggested to drive soil properties and ecosystem biogeochemistry (Freschet et al., 2012). Litter decomposition, a major pathway of nutrient fluxes, determines the organic matter input to soils, influences forest productivity and soil nutrient status (Vesterdal et al., 2008). As the litter decomposes, the nutrients contained within it enter the soil and become available for uptake by the vegetation or are lost to lower soil layers or forest streams through leaching.

The amount of litterfall closely parallels the biomass of foliage. Litterfall has been used as an index of NPP in a variety of plant communities. For example, Bray and Gorham (1964) found that annual leaf fall approximates total NPP if multiplied by
4.9 for temperate evergreen forest, by 3.7 for temperate deciduous forest and by 3.3 for equatorial forest. Aragao et al. (2009) opined that the total NPP is close to 3.1 times of total litterfall for the tropical forests of Amazonia. Therefore, precise estimation of litterfall rate is essential for the evaluation of ecosystem NPP and nutrient cycling. The quality of litter controls the rate of NPP. Tree species producing high quality litter (lower $\mathrm{C}: \mathrm{N}$ ratio) result in a higher rates of nutrient availability in the soil and in turn a higher rate of primary productivity.

The major factors affecting litter production are the temperature, age of the stand, species composition and soil fertility. Generally, the total litterfall declines with the maturity of the forest. Soil fertility promotes both total and foliar litterfall (Hansen et al., 2009). Chave et al. (2010) reported a positive relationship between litterfall seasonality and rainfall seasonality across 47 forest plots of tropical South America. Moreover, the addition of $\mathrm{P}$ significantly increased the fine-litter production in humid lowland forest of Panama (Wright et al., 2011).

In Nepal, only few studies have been made regarding the litter dynamics in tropical forest (Mandal, 1999) but the litter dynamics with respect to forest disturbance is not available. Therefore, present study was carried out in undisturbed and disturbed stands of moist tropical forest ecosystem in the eastern Nepal with following objectives: 1) to estimate the level of litterfall and litter mass in undisturbed and disturbed stands; 2) to understand the seasonal and monthly pattern of litterfall; 3 ) to assess the $\mathrm{C}$ content in litter and 4) to understand the contribution of litterfall to nutrients cycling in both forest stands. 


\section{Materials and methods \\ Study area}

The study was conducted in a Sal (Shorea robusta) dominated moist tropical forest of Sunsari District, eastern Nepal (latitude $26^{\circ} 41^{\prime} \mathrm{N}$ to $26^{\circ} 50^{\prime} \mathrm{N}$ and longitude $87^{\circ} 09^{\prime}$ $\mathrm{E}$ to $87^{\circ} 21^{\prime} \mathrm{E}$ ), within the altitude range of 220 to $370 \mathrm{~m}$ above msl (Fig. 1). The forest lies in the catchment area of Koshi River, one of the largest rivers in Nepal. The total area occupied by the forest is 11394 ha.

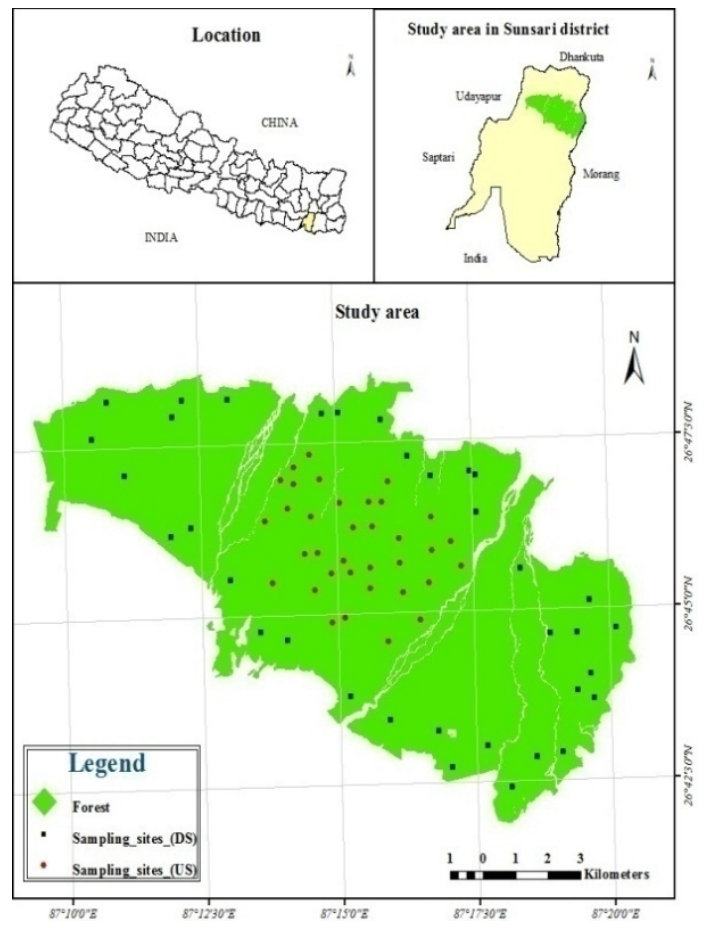

Figure 1. Map of the study area (tropical forest of Sunsari district, eastern Nepal).

The central part (core area) of the forest is relatively undisturbed, while the peripheral part is affected by disturbance activities as removal of timber, livestock grazing, fuel-wood and litter collection, tree lopping, removal of poles for house-hold constructions and forest fires. These distur- bances have caused deforestation, forest fragmentation and degradation and subsequent invasion of exotic species like Mikania micrantha, Lantana camara and Chromolaena odorata, which adversely affect the native plant diversity in the forest.

The climate is tropical and monsoon type with three distinct seasons: dry and warm summer (March to May), wet and warm rainy (June to October), and dry and cool winter (November to February). The mean monthly minimum and maximum air temperature during 2005-2014 ranged from $10.9^{\circ} \mathrm{C}$ to $25.3^{\circ} \mathrm{C}$ and $22.6^{\circ} \mathrm{C}$ to $33.2^{\circ} \mathrm{C}$, respectively. The average annual rainfall for the period was $1998.6 \mathrm{~mm}$ (Fig. 2). Relative humidity was higher in rainy season with highest value in August (92\%).

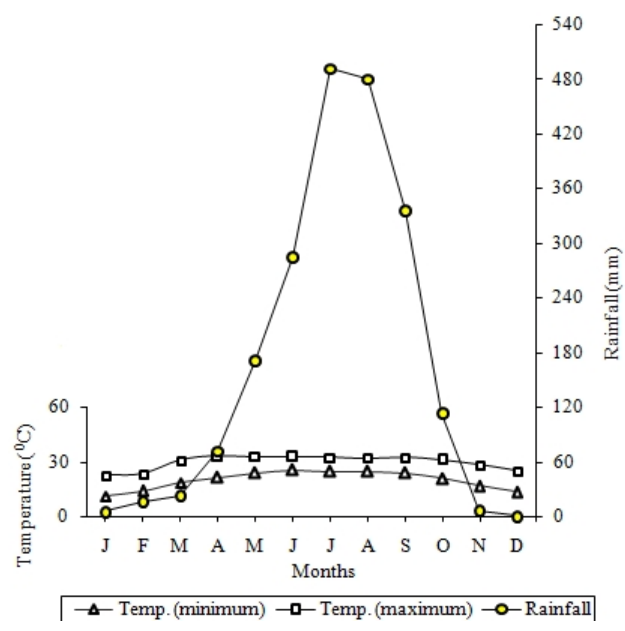

Figure 2. Ombrothermic representation of the climate of moist tropical forest region of Sunsari district, eastern Nepal. The data pertain to the period 2005-2014 (Source: Department of Meteorology, Dharan, Nepal).

The forest is bordered by the Siwalik hill in the north and the Gangetic alluvial plains in the south. The area has been formed from soft erodible sediments of the 
Siwaliks and is characterized by the presence of boulder beds mixed with sand, silt, clay imparting a porous nature. The soil mainly consists of deep alfisols.

The forest tree layer is dominated by Sal. Other main associates are Haldina cordifolia, Lagerstroemia parviflora, and Terminalia alata. Clerodendron viscosum and Murraya koenigii are some of the main shrub species while Chromolaena odorata and Achyranthes aspera are dominant herbs.

\section{Litterfall and litter mass estimation}

The forest was divided into 2 parts: i) the relatively undisturbed core area (treated as undisturbed forest stand; UF), and ii) the disturbed peripheral area (treated as disturbed forest stand; DF). Because of the following characters the core area was considered as UF: canopy area ranged between 153.8 and $226.9 \mathrm{~m}^{2}$, crown cover ranged from $70 \%-80 \%$, density of the tree was 466.4 individuals $\cdot \mathrm{ha}^{-1}$ and tree stumps were absent. The peripheral part of the forest is disturbed because of following characters: canopy area ranged between 28.3 and 77.5 $\mathrm{m}^{2}$, crown cover ranged from $30 \%-40 \%$, tree density was 234.3 individuals $\cdot \mathrm{ha}^{-1}$ and tree stump density was 70 stumps $\cdot \mathrm{ha}^{-1}$.

The litterfall and litter mass was estimated using 70 randomly established sample plots, 35 each in UF and DF. For the estimation of litterfall one litter trap (1 $\mathrm{m} \times 1 \mathrm{~m}$ ) was fixed on the forest floor at each of the seventy sampling plots. Litterfall was collected at monthly intervals from April 2011 to March 2012 and categorized into leaf and non-leaf components. Litter mass accumulated at each sampling plot was collected once every season from one 1 $\mathrm{m} \times 1 \mathrm{~m}$ plot.
The turnover rate $(\mathrm{k})$ of litter was calculated following Jenny et al. (1949) as: $\mathrm{k}=\mathrm{A} /(\mathrm{A}+\mathrm{F})$, where $\mathrm{A}$ is the annual litterfall and $\mathrm{F}$ is the mass of litter at steady state. In the present study, the $F$ value for leaf litter was assumed to be equal to the partly decayed leaf litter mass during the winter season, and for non leaf, equal to the non-leaf litter mass during the winter season. For total litter (leaf + non-leaf), F was assumed to be the sum of partly decayed leaf and non-leaf litter mass during the winter season. Turnover time, the reciprocal of turnover rate was expressed as: $\mathrm{t}=1 / \mathrm{k}$.

\section{Carbon estimation in litter}

The litter (leaf and non-leaf) samples were collected from each sampling plot. All the samples were oven dried at $80^{\circ} \mathrm{C}$ to constant weight, powdered and used separately for $\mathrm{C}$ analyses. Carbon present in plant materials was estimated by ash content method. Carbon concentrations were assumed to be approximately $50 \%$ of ash free weight (McBrayer and Cromack, 1980). In this method oven dried litter components were burnt separately in electric furnace at $400^{\circ} \mathrm{C}$. Ash content (inorganic elements in the form of oxides) left after burning was weighed and carbon concentration was calculated by using the following equation: $\%$ Carbon $=($ Initial weight - Ash weight $) \times$ $100 / 2$

The $\mathrm{C}$ stock in litter components was calculated by multiplying $\mathrm{C}$ concentration (a conversion factor) to dry weight. The conversion factors of 0.453 and 0.468 were obtained and used for leaf and non-leaf litter, respectively.

\section{Litter chemical analysis}

Litterfall samples (leaf litter and non-leaf litter) collected from the litter traps at 
monthly intervals were pooled together in proportion to their volume to represent annual samples for each site. The samples were oven dried at $80^{\circ} \mathrm{C}$ to constant weight and ground separately and passed through 1 $\mathrm{mm}$ mesh screen. Three separate samples of each component were analyzed for each site.

The total $\mathrm{N}$ concentration was determined by micro-Kjeldahl method (Peach and Tracey, 1956). Using the method outlined by Allen et al. (1974), a portion of the plant sample was digested in triacid mixture (1:5:1, perchloric : nitric : sulphuric acid) and $\mathrm{P}$ was determined colorimetrically, and $\mathrm{K}$ and calcium $(\mathrm{Ca})$ by atomic absorption spectrophotometer. Calcium was determined only in fresh green leaf and leaf litter samples. Lanthanum chloride was added in the samples used for the determination of Ca.

\section{Computation procedure}

The stocks of nutrients in the litter components were computed by multiplying the dry weights of components and their mean nutrient concentrations. The turnover rate (k) for each element on the forest floor was calculated as $\mathrm{k}=\mathrm{A} /(\mathrm{A}+\mathrm{F})$, (Jenny et al., 1949), where $A$ is the amount of nutrient added to the forest floor annually by litterfall and $\mathrm{F}$ is the nutrient content of the lowest value of standing crop of litter in the annual cycle. Turnover time (t) is the reciprocal of the turnover rate $(\mathrm{k})$ and is expressed as $\mathrm{t}=1 / \mathrm{k}$.

\section{Statistical analysis}

Statistical test (ANOVA) was carried out in SPSS (IBM Statistics, ver. 20) package to compare the mean litterfall between forest type (UF and DF) and season (Summer, rainy and winter).

\section{Results}

\section{Litterfall, litter mass and turnover}

The total annual litterfall in UF was 11.8 $\mathrm{Mg} \mathrm{ha}^{-1} \mathrm{yr}^{-1}$ which decreased by $54.2 \%$ in DF (Tab. 1). Leaves accounted for $69 \%$ (UF) to $76 \%$ (DF) of total litterfall while non-leaf litter formed the rest. Seasonal pattern exhibited a concentrated litterfall in summer season during March to June when more than $70 \%$ litterfall occurred in both stands (Figs. 3-5). The variation in litterfall due to the difference in forest type and season was significant $(\mathrm{P}<0.001)$ (Tab. 2). The proportion of litterfall was highest during April (more than 27\%) followed by March (more than 21\%) in both stands. Compared to leaf fall, a greater proportion of annual non-leaf litterfall (30\% in DF and $42 \%$ in UF) occurred during the rainy season.

Forest floor litter mass also decreased due to forest disturbance. The variation in litter mass due to the difference in forest type and season was significant $(\mathrm{P}<$ 0.001). In litter mass, fresh litter mass accounted $64 \%$ while partly decayed litter mass comprised $36 \%$ in both stands (Tab. 3 ). The turnover rate (per yr) of the total litter ranged from 0.79 in DF to 0.83 in UF (Tab. 4). The turnover time (the reciprocal of turnover rate) of the total litter ranged between 1.21 and 1.26 years in UF and DF indicating $83 \%$ and $79 \%$ replacement of litter on the forest floor each year in these sites respectively.

\section{Nutrient return through litterfall}

The concentrations of all nutrients in leaf litter were higher than in non-leaf litter in both stands (Tab. 5). The total input of nutrients $\left(\mathrm{kg} \mathrm{ha}^{-1} \mathrm{yr}^{-1}\right)$ to the soil through litterfall in UF was more than double $(99.7 \mathrm{~N}$, 
Table 1. Annual litterfall $\left(\mathrm{Mg} \mathrm{ha}^{-1} \mathrm{yr}^{-1}\right)$ with their carbon stocks $\left(\mathrm{Mg} \mathrm{C} \mathrm{ha}^{-1} \mathrm{yr}^{-1}\right)$ in undisturbed and disturbed stands of moist tropical forest in Sunsari district, eastern Nepal.

\begin{tabular}{llllllll}
\hline \multirow{2}{*}{ Litter components } & \multicolumn{3}{c}{ Undisturbed forest } & & \multicolumn{3}{c}{ Disturbed forest } \\
\cline { 2 - 3 } \cline { 6 - 7 } & Litterfall & Carbon stocks & \% & & Litterfall & Carbon stocks & \% \\
\hline Leaf & $8.1 \pm 0.50$ & 3.67 & 69 & & $4.1 \pm 0.06$ & 1.86 & 76 \\
Non-leaf & $3.7 \pm 0.03$ & 1.73 & 31 & & $1.3 \pm 0.01$ & 0.59 & 24 \\
\hline Total & $11.8 \pm 0.70$ & 5.40 & 100 & & $5.4 \pm 0.13$ & 2.45 & 100 \\
\hline
\end{tabular}

Table 2. F values of the effects of forest stand, season and litter type on litterfall as obtained by analysis of variance (at 95\% confidence interval).

\begin{tabular}{lll}
\hline Factors & F values & Significance level \\
\hline Forest type & 2101.3 & $\mathrm{P}<0.001$ \\
Season & 4753.7 & $\mathrm{P}<0.001$ \\
Forest type * Season & 693.8 & $\mathrm{P}<0.001$ \\
\hline
\end{tabular}

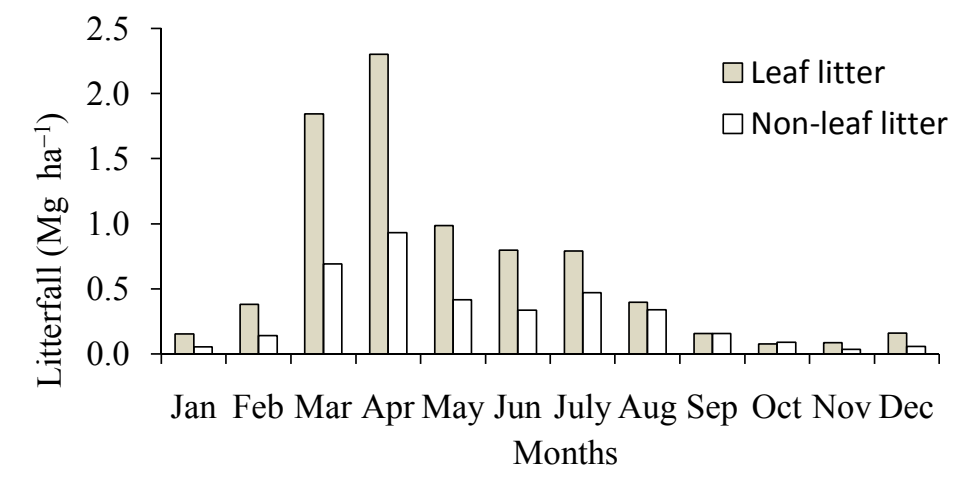

Figure 3. Monthly litterfall in undisturbed stand of moist tropical forest in Sunsari district, eastern Nepal.

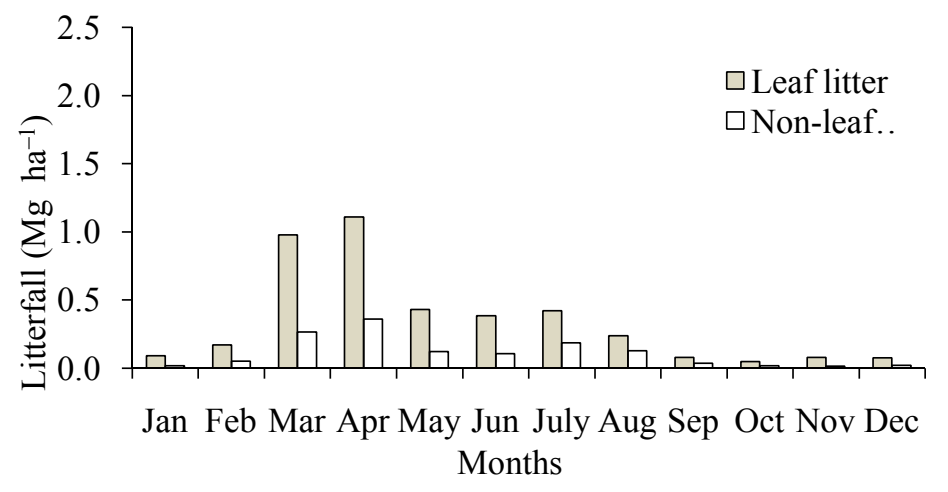

Figure 4. Monthly litterfall in disturbed stand of moist tropical forest in Sunsari district, eastern Nepal. 


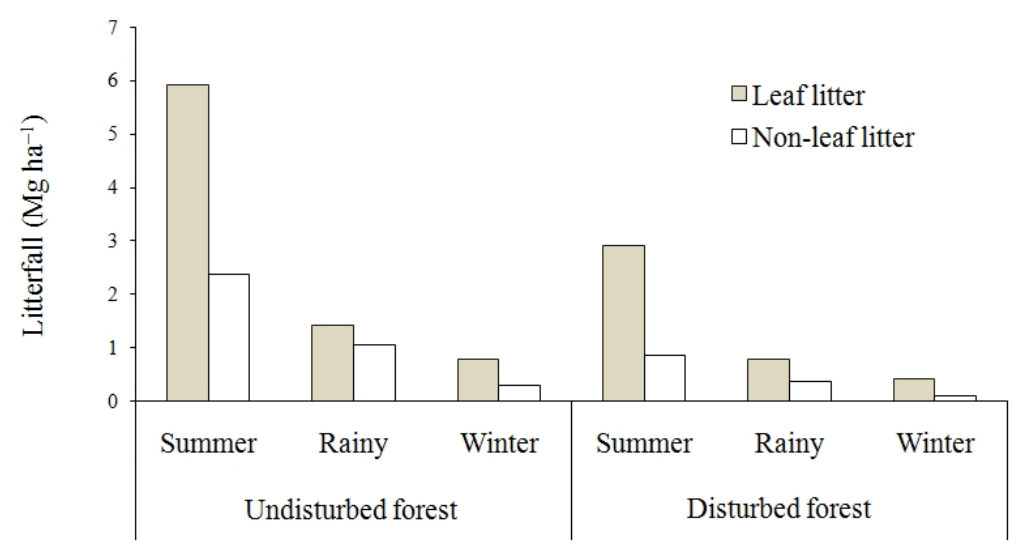

Seasons

Figure 5. Seasonal variation in litterfall in undisturbed and disturbed stands of moist tropical forest in Sunsari district, eastern Nepal.

Table 3. Forest floor litter mass $\left(\mathrm{Mg} \mathrm{ha}^{-1} \pm \mathrm{SE}\right.$, average of three seasons) in tropical moist forest of eastern Nepal. Values in parentheses are percentage of the total.

\begin{tabular}{lllllll}
\hline \multirow{2}{*}{ Litter mass components } & \multicolumn{2}{c}{ Undisturbed forest } & & \multicolumn{2}{c}{ Disturbed forest } \\
\cline { 2 - 3 } & Litter mass & \% of total & & Litter mass & \% of total \\
\hline Fresh leaf & 2.7 & 40 & & 1.5 & 42 \\
Non-leaf & 1.6 & 24 & & 0.77 & 22 \\
Partly decayed leaf & 1.4 & 21 & & 0.83 & 23 \\
Partly decayed non-leaf & 1 & 15 & & 0.47 & 13 \\
\hline Total & $6.7 \pm 0.35$ & 100 & & $3.6 \pm 0.22$ & 100 \\
\hline
\end{tabular}

Table 4. Turnover (rate and time) of litter in tropical moist forest of eastern Nepal.

\begin{tabular}{lccccccc}
\hline \multirow{2}{*}{ Turnover } & \multicolumn{3}{c}{ Undisturbed forest } & & \multicolumn{3}{c}{ Disturbed forest } \\
\cline { 2 - 4 } \cline { 6 - 8 } & Leaf litter & Non-leaf litter & Total & & Leaf litter & Non-leaf litter & Total \\
\hline Rate (k/year) & 0.85 & 0.77 & 0.83 & & 0.82 & 0.73 & 0.79 \\
Time (t, years) & 1.17 & 1.3 & 1.21 & & 1.22 & 1.38 & 1.26 \\
\hline
\end{tabular}

Table 5. Concentration of nutrients $(\%)($ mean $\pm \mathrm{SE})$ in litter of moist tropical forest in Sunsari district, eastern Nepal.

\begin{tabular}{lcccc}
\hline Components & $\mathbf{N}$ & $\mathbf{P}$ & $\mathbf{K}$ & $\mathbf{C a}$ \\
\hline Leaf litter & & & & \\
Trees & $0.85 \pm 0.05$ & $0.08 \pm 0.003$ & $0.62 \pm 0.04$ & $1.13 \pm 0.08$ \\
Shrubs & $1.1 \pm 0.09$ & $0.09 \pm 0.007$ & $0.65 \pm 0.05$ & $1.03 \pm 0.06$ \\
Herbs & $0.81 \pm 0.04$ & $0.07 \pm 0.006$ & $0.8 \pm 0.05$ & $1.03 \pm 0.07$ \\
Mean & $0.92 \pm 0.05$ & $0.08 \pm 0.005$ & $0.69 \pm 0.06$ & $1.06 \pm 0.06$ \\
\hline Non leaf litter & & & & \\
Trees & $0.66 \pm 0.05$ & $0.05 \pm 0.003$ & $0.22 \pm 0.01$ & \\
Shrubs & $0.7 \pm 0.07$ & $0.05 \pm 0.003$ & $0.24 \pm 0.02$ & \\
Mean & $0.68 \pm 0.05$ & $0.05 \pm 0.004$ & $0.23 \pm 0.01$ & \\
\hline
\end{tabular}


Table 6. Amount of nutrients $\left(\mathrm{kg} \mathrm{ha}^{-1} \mathrm{yr}^{-1}\right)$ in litterfall in undisturbed and disturbed stands of moist tropical forest of Sunsari district, eastern Nepal (mean $\pm \mathrm{SE})$.

\begin{tabular}{|c|c|c|c|c|c|c|}
\hline \multirow{2}{*}{ Components } & \multicolumn{3}{|c|}{ Undisturbed forest } & \multicolumn{3}{|c|}{ Disturbed forest } \\
\hline & $\mathbf{N}$ & $\mathbf{P}$ & $\mathbf{K}$ & $\mathbf{N}$ & $\mathbf{P}$ & $\mathbf{K}$ \\
\hline Leaf & $74.5 \pm 6.5$ & $6.5 \pm 0.4$ & $55.9 \pm 5.6$ & $37.7 \pm 2.8$ & $3.3 \pm 0.1$ & $28.3 \pm 2.4$ \\
\hline Non leaf & $25.2 \pm 1.6$ & $1.9 \pm 0.1$ & $8.5 \pm 0.7$ & $8.8 \pm 0.5$ & $0.7 \pm 0.05$ & $3.0 \pm 0.02$ \\
\hline Total & $99.7 \pm 8.0$ & $8.3 \pm 0.7$ & $64.4 \pm 4.1$ & $46.6 \pm 3.3$ & $3.9 \pm 0.2$ & $31.3 \pm 2.6$ \\
\hline
\end{tabular}

8.3 P, and $64.4 \mathrm{~K})$ as compared to DF (46.6 N, 3.9 P, and 31.3 K) (Tab. 6). The contribution of different nutrients in the input to the soil through litterfall was in the order: $\mathrm{N}$ $>\mathrm{K}>\mathrm{P}$ in both stands. Of the total annual nutrient input through litterfall, leaf litter accounted for $78-87 \%$ in UF and $85-90 \%$ in DF.

\section{Nutrients in litter mass and turnover of nutrients on forest floor}

Litter on the forest floor (litter mass) varies seasonally with litterfall. Standing state of nutrients in litter mass decreased with forest disturbance. The nutrient stocks in litter mass were in the order: $\mathrm{N}>\mathrm{K}>\mathrm{P}$ in both stands (Tab. 7). Leaf litter contributed 68$82 \%$ of total nutrients in UF and $72-85 \%$ in DF. Of the total nutrients in litter mass, 63 $65 \%$ nutrients were present in fresh litter and rest in partly decayed litter.

The values of turnover rate and turnover time for different litter nutrients on the forest floor are given in Table 8. The turnover rate of nutrients ranged 0.67-0.69 for $\mathrm{N}, 0.66-0.68$ for $\mathrm{P}$ and $0.64-0.66$ for $\mathrm{K}$. The turnover rates were slightly higher in the UF and lower in the DF. The turnover time of litter nutrients ranged 1.45-1.49 for $\mathrm{N}, 1.47-1.51$ for $\mathrm{P}$ and 1.53-1.55 for $\mathrm{K}$. Turnover time for all nutrients were relatively higher in DF which may be due to immobilization of these nutrients in litter mass by the microorganisms.

\section{Discussion \\ Litterfall and litter mass}

Litterfall and fine roots are important vectors of nutrient and $\mathrm{C}$ recycling in forest ecosystems. Total $\mathrm{C}$ input into soil through litter plus root turnover in present forest was previously reported by Gautam and Mandal (2016). Their turnover is usually determined by biotic factors (species, age groups, canopy cover) and weather conditions.

Table 7. Standing state of nutrients $\left(\mathrm{kg} \mathrm{ha}^{-1}\right)($ mean $\pm \mathrm{SE})$ in litter layer in moist tropical forest of Sunsari district, eastern Nepal.

\begin{tabular}{lcccccccc}
\hline \multirow{2}{*}{ Components } & \multicolumn{3}{c}{ Undisturbed forest } & & \multicolumn{3}{c}{ Disturbed forest } \\
\cline { 2 - 4 } \cline { 8 - 9 } & $\mathbf{N}$ & $\mathbf{P}$ & $\mathbf{K}$ & & & $\mathbf{N}$ & $\mathbf{P}$ & $\mathbf{K}$ \\
\hline Total littermass & $55.4 \pm 4.3$ & $4.6 \pm 0.3$ & $34.3 \pm 2.8$ & & $29.9 \pm 1.5$ & $2.5 \pm 0.1$ & $18.9 \pm 1.1$ \\
Fresh leaf litter (\%) & 45 & 47 & 54 & & 46 & 48 & 55 \\
Partly decayed leaf litter (\%) & 23 & 24 & 28 & & 26 & 27 & 30 \\
Fresh non-leaf litter (\%) & 20 & 17 & 11 & & 18 & 15 & 9 \\
Partly decayed non-leaf litter (\%) & 12 & 11 & 7 & & 11 & 9 & 6 \\
\hline
\end{tabular}


Table 8. Turnover rate $(k)$ and turnover time $(t)$ of litter nutrients on forest floor in moist tropical forest of Sunsari district, eastern Nepal.

\begin{tabular}{lcccccccc}
\hline \multirow{2}{*}{ Turnover rate and time } & \multicolumn{3}{c}{ Undisturbed forest } & & \multicolumn{3}{c}{ Disturbed forest } \\
\cline { 2 - 4 } \cline { 7 - 9 } & $\mathbf{N}$ & $\mathbf{P}$ & $\mathbf{K}$ & & & $\mathbf{N}$ & $\mathbf{P}$ & $\mathbf{K}$ \\
\hline Rate (per yr) & 0.69 & 0.68 & 0.66 & & & 0.67 & 0.66 & 0.64 \\
Time (yr) & 1.45 & 1.47 & 1.53 & & & 1.49 & 1.51 & 1.55 \\
\hline
\end{tabular}

Table 9. Litterfall $\left(\mathrm{Mg} \mathrm{ha}^{-1} \mathrm{yr}^{-1}\right)$ in different forests of the World.

\begin{tabular}{llll}
\hline Locality and forest types & Leaf litter & Total litter & References \\
\hline India (Uttarakhand) & - & $6.25 \pm 0.26$ & Rawat (2012) \\
South America (Tropical) & - & $8.61 \pm 1.91$ & Chave et al. $(2010)$ \\
South America (Tropical) & - & $8.01 \pm 3.41$ & Chave et al. $(2010)$ \\
India (Sub-tropical) & - & 5.47 & Pandey et al. $(2007)$ \\
India (Tropical) & - & $3.9-5.2$ & Swamy et al. $(2010)$ \\
Indonesia (Borneo) & $5.1-11.0$ & - & Paoli and Curran (2007) \\
India (Dry tropical) & - & $13.27-13.51$ & Pragasan and Parthasarathy \\
Brazil (Tropical) & $8.55-11.01$ & $12.32-14.74$ & Schessl et al. (2008) \\
Nepal (Moist tropical, Plateau Sal) & $7.2 \pm 0.31$ & $10.3 \pm 0.61$ & Mandal (1999) \\
Nepal (Moist tropical) & $4.1-8.1$ & $5.4-11.8$ & Present study \\
\hline
\end{tabular}

Mean annual litterfall of the forest combining both UF and DF amounted to $8.6 \mathrm{Mg}$ $\mathrm{ha}^{-1} \mathrm{yr}^{-1}$ (equivalent to $3.93 \mathrm{Mg} \mathrm{C} \mathrm{ha}$ $\left.\mathrm{yr}^{-1}\right)$. More than double litter production in UF of the studied forest compared to DF suggests that leaf litter production is susceptible to the forest disturbance which may have effects on overall forest dynamics. The total litterfall in UF is in lower range for that in tropical forests of Panama and Brazil, while it is convincingly higher than the value for tropical old-growth and secondary forests of South America, and other forests of Asia (Tab. 9). The NPP allocation to the annual litterfall of UF is almost equal to that of Amazonian forests (Malhi et al., 2014, 4.94-5.39 $\mathrm{Mg} \mathrm{C}^{-1}$ $\mathrm{yr}^{-1}$; Doughty et al., 2013, 4.52-5.03 Mg C $\mathrm{ha}^{-1} \mathrm{yr}^{-1}$ ), and lowland tropical rain forest of Central French Guiana (Chave et al., 2008, 4.65 $\left.\mathrm{Mg} \mathrm{C}^{-1} \mathrm{yr}^{-1}\right)$.
The contribution of leaf litter to total litterfall ranged between $69 \%$ (at UF) to $76 \%$ (at DF). Malhi et al. (2014) reported almost same range of $72-74 \%$ allocation in leaf fall while Girardin et al. (2014) reported a range of $69-73 \%$. The higher percentage of leaf litter and lower percentage of non-leaf litter in DF as compared to UF may be linked to the lopping of tree twigs for fodder which prevents the plant from flowering and fruiting, thereby reducing the quantity of non-leaf litter. On the other hand, in poor soils as in DF, forests tend to invest less into the construction of reproductive organs relative to photosynthesis but when resources are well supplied the excess in resources is made available for reproduction (Chave et al., 2010).

Litter production showed distinct seasonality peaking during dry summer season. Same trend was also reported in 
past studies (Pragasan and Parthasarathy, 2005; Doughty et al., 2013; Malhi et al., 2014). This is likely to be related to the low soil moisture level during this period resulted due to a strong and continuous solar radiation. Moreover, water stress stimulates the synthesis of abscissic acid in the leaf, which in turn leads to senescence and finally to leaf fall.

The annual litter turnover rate was faster in UF as compared to DF (Tab. 3). It may be associated with the higher microbial biomass and their activities in the soil of UF (Gautam and Mandal, 2014). Relatively faster turnover rate of leaf litter than that of the non-leaf litter in both stands may be due to the presence of relatively lower amount of lignified tissues (low lignin and high nitrogen) in leaves as compared to non-leaf components. Annual litter turnover value of present forest is comparable to the wet tropical evergreen forest of India i.e. 0.92-0.96 as reported by Swamy et al. (2010).

In the present study, turnover time of litter ranged between 1.21 (in UF) and 1.26 years (in DF) which is in range to the several tropical forests of World (Vogt et al., 1986). However, these values are slightly higher than the values reported for tropical wet evergreen forests (1.04 and 1.08 years) of Western Ghats India (Swamy et al., 2010).

\section{Nutrient retranslocation and nutrient-use efficiency}

Litter fall is a major functional part of any ecosystem as it plays a key role in regulating nutrient cycling and organic matter content. Nutrient return to the soil pool is mainly defined by litterfall (62-64\% for $\mathrm{N}$, $64-66 \%$ for $\mathrm{P}$ and $57-58 \%$ for $\mathrm{K}$ ), and rest is contributed by fine roots. Of the total annual nutrient input through litter fall, leaf litter accounted for $75-87 \%$ in UF and $81-$ $90 \%$ in DF.

Nutrient return via litterfall in the present study was in the range as reported by Vitousek and Sanford (1986) for several moist tropical forests and by Mandal (1999) in the Sal forest ecosystem of Nepal Himalaya. Rapid turnover of litter in the UF may continually regenerate the available $\mathrm{N}, \mathrm{P}$ and $\mathrm{K}$ to support a high net production of vegetation on UF (Gautam and Mandal, 2016).

\section{Conclusions}

Present study tried to disclose the functional aspect of moist tropical forest ecosystem in context of disturbance in ecologically fragile and socially marginal environment in the foothills of the Himalayas in eastern Nepal. Forest disturbance has reduced the litterfall, and consequently nutrients and carbon pools in substantial amounts. Human intervention in terms of lopping, litter removal, tree felling, grazing, fire etc. have been identified as key forest disturbances responsible for degradation of forest in peripheral parts adjoining human habitation. Such activities should be strictly prohibited by imposing rules and regulations so that status of biodiversity would be restored. Further, the information on carbon content in litterfall will be useful to mitigate climate change issues as per the objective of $\mathrm{REDD}^{+}$(Reducing Emissions from Deforestation and Forest Degradation).

\section{Acknowledgements}

The authors are grateful to the Head, Department of Botany, Post Graduate Campus, Tribhuvan University, Biratnagar, Nepal for providing laboratory and library facilities. First author is thankful to the University Grants Commission, Nepal for 
Scholarship. Our heartfelt thanks go to Mr. K.P. Bhattarai who helped in data collection and laboratory analysis.

\section{References}

Allen, S.E., H.M. Grimshaw, J.A. Parkinson and C. Quarmby 1974. Chemical Analysis of Ecological Materials. Blackwell Scientific Publications, Oxford.

Aragão, L.E.O.C., Y. Malhi, D.B. Metcalfe, J.E. Silva-Espejo, E. Jiménez, D. Navarrete, S. Almeida, A.C.L. Costa, N. Salinas, O.L. Phillips, L.O. Anderson, E. Alvarez, T.R. Baker, P.H. Goncalvez, J. Huamán-Ovalle, M. MamaniSolórzano, P. Meir, A. Monteagudo, S. Patiño, M.C. Peñuela, A. Prieto, C.A. Quesada, A. Rozas-Dávila, A. Rudas, J.A. Silva Jr, and R. Vásquez 2009. Above- and below-ground net primary productivity across ten Amazonian forests on contrasting soils. Biogeosci. 6: 27592778.

Baltzinger, M., F. Archaux and Y. Dumas 2012. Tree litter and forest understorey vegetation: a conceptual framework to understand the effects of tree litter on a perennial geophyte, Anemone nemorosa. Ann. Botany 109: 1175-1184.

Bernard Riéra and Pierre Charles-Dominique (2008). Above-ground biomass and productivity in a rain forest of Eastern South America. Journal of Tropical Ecology 24: 355-366. doi 10.1017/S0266467408005075

Bray, J.R. and E. Gorham 1964. Litter production in forests of world. Adv. in Ecol. Res. 2: 101-157.

Chave, J., D. Navarrete, S. Almeida, E. Alvarez, L.E.O.C. Aragão, D. Bonal, P. Chatelet, J.E. Silva-Espejo, J.Y. Goret, P. von Hildebrand, E. Jimenez, S. Patino, M.C. Penuela, O.L. Philips, P. Stevenson and Y. Malhi 2010. Regional and seasonal patterns of litterfall in tropical South America. Biogeosci. 7: 43-55.

Chave, J., J. Olivier, F. Bongers, P. Châtelet, P.-M. Forget, P. van der Meer, N. Norden, B. Riera, and P. Charles-Dominique 2008. Above-ground biomass and productivity in a rain forest of eastern South America. J. of Trop. Ecol. 24: 355-366.

Doughty, C.E., D.B. Metcalfe, M.C. da Costa, A.A.R. de Oliveira, G.F.C. Neto, J.A. Silva, L.E.O.C. Aragão, S.S. Almeida, C.A. Quesada, C.A.J. Girardin, K. Halladay, A.C.L. da Costa and Y. Malhi 2013. The production, allocation and cycling of carbon in a forest on fertile terra preta soil in eastern Amazonia compared with a forest on adjacent infertile soil. Plant Ecol. and Diver. 7: 41-53.

Freschet, G.T., R. Aerts and J.H.C. Cornelissen 2012. A plant economics spectrum of litter decomposability. Funct. Ecol. 26: 56-65.

Gautam, T.P. and T.N. Mandal 2014. Effect of disturbance and seasonality on soil microbial biomass in moist tropical forest of eastern Nepal. Geobios 41: 99-105.

Gautam, T.P. and T.N. Mandal 2016. Effect of disturbance on biomass, production and carbon dynamics in moist tropical forest of eastern Nepal. Forest Ecosystems 3: 2-10. doi 10.1186/s40663016-0070-y.

Girardin, C.A.J., J.E.S. Espejob, C.E. Doughty, W.H. Huasco, D.B. Metcalfe, L. Durand-Baca, T.R. Marthews, L.E.O.C. Aragao, W. Farfán-Rios, K. García-Cabrera, K. Halladay, J.B. Fisher, D.F. Galiano-Cabrera, L.P. Huaraca-Quispe, I. Alzamora-Taype, L. Eguiluz-Mora, N. SalinasRevilla, M.R. Silman, P. Meir and Y. Malhi 2014. Productivity and carbon allocation in a tropical montane cloud forest in the Peruvian Andes. Plant Ecol. and Diver. 7: 107-123.

Hansen, K., L. Vesterdal, I.K. Schmidt, P. Gundersen, L. Sevel, A. Bastrup-Birk, L.B. Pedersen and J. Bille-Hansen 2009. Litterfall and nutrient return in five tree species in a common garden experiment. Forest Ecol. Manage. 257: 2133-2144.

Jenny, H., S.P. Gessel and F.T. Bingham 1949. Comparative study of decomposition rates of organic matter in temperate and tropical region. Soil Sci. 68: 419-432.

Malhi, Y., F. Farfán Amézquita, C.E. Doughty, J.E. Silva-Espejo, C.A.J. Girardin, D.B. Metcalfe, L.E.O.C. Aragão, L.P. Huaraca-Quispe, I. Alzamora-Taype, L. Eguiluz-Mora, T.R. Marthews, K. Halladay, C.A. Quesada, A.L. Robertson, J.B. Fisher, J. Zaragoza-Castells, C.M. Rojas-Villagra, Y. Pelaez-Tapia, N. Salinas, P. Meir and O.L. Phillips 2014. The productivity, metabolism and carbon cycle of two lowland tropical forest plots in south-western Amazonia, Peru. Plant Ecol. and Diver. 7: 85-105.

Mandal, T.N. 1999. Ecological analysis of recovery of landslide damaged Sal forest ecosystem in Nepal Himalaya. Banaras Hindu University, Varanasi, India. (Ph.D. thesis)

McBrayer, J.F. and K.J. Cromack 1980. Effect of snowpack on oak- litter breakdown and nutrient release in a Minnesota forest. Pedobiologia 20: 47-54. 
Pandey, R.R., G. Sharma, S.K. Tripathi and A.K. Singh 2007. Litterfall, litter decomposition and nutrient dynamics in a subtropical natural oak forest and managed plantation in northeastern India. Forest Ecol. Manage. 240: 96-104.

Paoli, G.D. and L.M. Curran 2007. Soil nutrients limit fine litter production and tree growth in mature lowland forest of Southwestern Borneo. Ecosystems 10: 503-518.

Peach, K. and M.V. Tracey 1956. Modern Methods of Plant Analysis. Vol. 1, Springer-Verlag, Berlin.

Pragasan, L.A. and N. Parthasarathy 2005. Litter production in tropical dry evergreen forests of south India in relation to season, plant life-forms and physiognomic groups. Curr. Sci. 88: 12551263.

Rawat, V.S. 2012. Litter fall, fine root biomass and soil nutrient returns in Van Panchayat Forest of Uttarakhand. J. of Asian Sci. Res. 2: 325-333.

Schessl, M., W. Luiz da Silva and G. Gottsberger 2008. Effects of fragmentation on forest structure and litter dynamics in Atlantic rain forest in Pernambuco, Brazil. Flora 203: 215-228.
Swamy, S.L., C.B.S. Dutt, M.S.R. Murthy, A. Mishra and S.S. Bargali 2010. Floristics and dry matter dynamics of tropical wet evergreen forests of Western Ghats, India. Curr. Sci. 99: 353-364.

Vesterdal, L., I.K. Schmidt, I. Callesen, L.O. Nilsson and P. Gundersen 2008. Carbon and nitrogen in forest floor and mineral soil under six common European tree species. Forest Ecol. Manage. 255: 35-48.

Vitousek, P.M. and R.L. Sanford Jr. 1986. Nutrient cycling in moist tropical forest. Ann. Reviw of Ecol. Syste. 17: 137-167.

Vogt, K.A., C.C. Grier and D.J. Vogt 1986. Production, turnover and nutrient dynamics of aboveand belowground detritus of world forests. $A d v$. in Ecol. Res. 15: 303-377.

Wright, S.J., J.B. Yavitt, N. Wurzburger, B.L. Turner, E.V.J. Tanner, E.J. Sayer, L.S. Santiago, M. Kaspari, L.O. Hidin, K.E. Harms, M.N. Garcia and M.D. Corre 2011. Potassium, phosphorus, or nitrogen limit root allocation, tree growth, or litter production in a lowland tropical forest. Ecology 92:1616-1625. 